\title{
Peningkatan Ketrampilan Metakognisi Mahasiswa IKIP Budi Utomo Malang Melalui Penerapan Tutor Sebaya Dipadukan dengan The Power of Two dalam Matakuliah Kimia Dasar
}

\author{
Wilyati Agustina \\ Program Studi Pendidikan Biologi IKIP Budi Utomo \\ Jalan Simpang Arjuno 14-B Malang \\ wilyanti_b@yahoo.com
}

\begin{abstract}
Based on the observation showed that the student's do not use the concept they had to solve new problems that is solved by using they had. The basic chemical is general courses that must be taken by students of MIPA (Mathematics and Science), where subjects are abstract and difficult to understand, the calculation of the chemical needs to optimize the students' ability, it is expected to be able to form: independent personality, patterned science thought, creative, and an objective that has a character (soft skills) in appearance, attitude, and behavior levels. One of the parameters to find out is through the skill improvement metacognition. In the reserach problem is wether peer teaching merged with the power of two in The basic chemical can improve IKIP Budi Utomo student'smetacognitive skill. The design of this reserch is Class action reserach that developed by Kemmis and Taggart. There are four steps/ phases. 1) planning, 2) acting, 3) observing, 4) analyzing and reflecting. The result of study reserach, there is significant improvement from the average of cicle I to II from 44,5 score- 69,3 and the score of completness is 40,3\%
\end{abstract}

Keywords: metacognitive skill, peer teaching, power of two, basic chemical

Kimia Dasar merupakan salah satu matakuliah wajib yang harus ditempuh oleh mahasiswa program studi Pendidikan Biologi dan Program Studi Pendidikan Matematika di IKIP Budi Utomo. Kimia merupakan salah satu matakuliah yang dianggap sulit dan mahasiswa cenderung mendapatkan nilai yang rendah. Wiseman (1981), Nakhleh (1992) banyak siswa kesulitan dalam memahami prinsip dan konsep kimia disebabkan sifatnya yang abstrak. Dan berdasarkan hasil pengamatan mahasiswa belum menggunakan konsep yang dimiliki untuk memecahkan permasalahanpermasalahan yang diberikan dalam tugas baru yang dapat dipecahkan dengan menggunakan konsep yang telah dimilikinya. Pendapat Gagne bahwa pemecahan masalah akan tumbuh dengan sendirinya jika siswa belajar dengan baik di kelas, pandangan ini sudah berubah guru mengajak siswa untuk aktif dan berpikir ilmiah menjadikan pemecahan masalah sebagai obyek.

Pemecahan masalah yang disajikan oleh guru selama proses pembelajaran akan memberikan kesempatan siswa untuk berpikir secara ilmiah sehingga peserta didik dapat membangun sendiri pengetahuan dan kemampuan mereka. Oleh karena itu mahasiswa diharapkan mampu menentukan tujuan dan berusaha mencapai tujuannya memutuskan strategi belajar apa yang akan digunakan, mengatur diri sendiri,dan mengembangkan diri,dan memotivasi diri sendiri.

Mengatasi permasalahan diatas maka diperlukan peningkatan kualitas mahasiswa perlu ditingkatkan melalui proses pembelajaran yang bersifat kontruktivisme (Zubaidah, 2009). Salah satu strategi pembelajaran yang berorentasi kontruktivistik dan learning community yaitu pembelajaran cooperative learning (Arend, 2004 dalam Muhfaroyin 2009). Pembelajaran Kooperatif adalah pendekatan pembelajaran yang berfokus pada penggunaan kelompok kecil siswa untuk bekerja sama dalam memaksimalkan kondisi belajar untuk mencapai tujuan belajar (Supriyono:2006). Tujuan dari pembelajaran Kooperatif adalah 1) Meningkatkan hasil belajar akademik, 2) Penerimaan terhadap keragaman karakter peserta didik dan kondisi untuk bekerja sama saling bergantung satu sama lain atas tugas-tugas bersama, 3) Pengembangan ketrampilan sosial, mengajarkan kolaborasi 
untuk saling berinteraksi dan kerjasama dengan teman sebaya (Suprijono:2006). Salah satu pembelajaran Kooperatif yang dapat diterapkan adalah Tutor Sebaya dipadukan dengan The Power of Two. Arikunto (1986:77) bahwa tutor sebaya adalah seseorang atau beberapa orang siswa yang ditunjuk oleh guru sebagai pembantu guru dalam melakukan bimbingan terhadap kawan sekelas. Berdasarkan hasil penelitian Aditya (2013)_metode tutor sebaya terhadap hasil belajar dribble bola basket yang dibuktikan dari nilai thitung 6,34 $>$ ttabel 2,056 dengan taraf signifikan 0,05. Sedangkan besar pengaruhnya diketahui sebesar $17,01 \%$. Strategi The Power of Two adalah strategi belajar kekuatan berdua (the power of two) dimana kegiatan dilakukan untuk meningkatkan belajar kolaboratif dan mendorong munculnya keuntungan dari sinergi itu, sebab dua orang tentu lebih baik daripada satu (Muqowin dalam Sajana :2007). Berdasarkan hasil penelitian Mirdanda (2014) memberikan hasil yang sangat signifikan $\mathrm{rxy}=0,46$.

Berdasarkan dari uraian diatas dirumuskan masalah apakah Penerapan Tutor Sebaya dipadukan dengan The Power of Two dalam Matakuliah Kimia Dasar dapat meningkatkan ketrampilan Metakognisi Mahasiswa IKIP Budi Utomo Malang? Metakognitif (metakognisi) adalah pengetahuan tentang belajarnya diri sendiri (Flavell, 1985; Graner dan Alexander, 1989 dalam Nur, 2008). Dapat dikatakan bahwa keterampilan metakognitif adalah keterampilan dimana seseorang tahu cara belajar yang sesuai dengan dirinya. Dan cara untuk meningkatkan kesadaran mengenai proses berpikir dan pembelajaran yang berlaku sehingga bila kesadaran ini terwujud, maka akan timbul ketrampilan metakognisi di mana seseorang dapat mengawal pikirannya dengan merancang, memantau dan menilaiapayangdipelajarinya.(Coreibima:2009). Tujuan pemberdayaan ketrampilan metakognisi adalah agar siswa memahami bagaimana tugas itu dilaksanakan dan pengembangan siswa ditujukkan agar siswa dapat memantau perkembangan belajarnya sendiri.

Salah satu cara untuk memperbaiki pola pemikiran peserta didik dengan meningkatkan ketrampilan metakognisi yang berisi kegiatan orientasi, perencanaanpenyesuaian pemantauan, evaluasi dan refleksi (Nur:2008).

\section{METODE}

Rancangan penelitian yang dikembangkan oleh Kemiis dan Taggart (Soedarsono,1997) adalah penelitian tindakan kelas (classroom action research). Pelaksanaanya berlangsung dalam dua siklus dan setiap siklus terdiri 4 tahap, yaitu (1) rencana, (2) tindakan, (3) Observasi, (4) analisis dan refleksi. Pelaksanaan penelitian tahun ajaran 2014/2015 bulan Oktober- Desember 2014, mahasiswa angkatan 2014 kelas A sebanyak 40 orang yang merupakan peserta matakuliah Kimia Dasar. Data di analisis secara deskriptif. Instrumen yang digunakan lembar format observasi penilaian ketrampilan metakognisi.

\section{HASIL}

Penerapan Tutor Sebaya dipadukan dengan The Power of Two dalam Matakuliah Kimia Dasar dapat meningkatkan ketrampilan Metakognisi Mahasiswa IKIP Budi Utomo Malang ini dapat dilihat dalam proses pembelajaran maupun hasil pembelajaran yang menunjukkan adanya peningkatan dari siklus I ke siklus II berdasarkan komponen yang diamati.

Langkah-langkah dalam proses pembelajaran: 1) Langkah pertama, Pengajar membagi peserta didik menjadi beberapa kelompok, setiap kelompok terdiri dari 2-3 orang. 2) Langkah kedua, membuat problem atau permasalahan, 3) Langkah ketiga, membuat perencanaan jawaban dengan teman sebaya, 4) Langkah keempat, peserta didik menyediakan data dasar untuk menjawab permasalahan, 5) Langkah kelima, diskusi berpasang-pasangan, 6) Langkah keenam mendiskusikan hasil pemecahan masalahnya.

\section{Peningkatan Ketrampilan Metakognisi dalam Proses Pembelajaran}

Ketrampilan metakognisi dalam proses pembelajaran sikuls I dan siklus II ditunjukan proses yaitu, 1) ketrampilan perencanaan (planning Skills), 2) ketrampilan monitoring (monitoring skills), 3) ketrampilan evaluasi (evaluation skills), 4) ketrampilan prediksi (prediction skills). Peningkatan rerata skor dan persentase pencapaian ketrampilan metakognisi mahasiswa dari sikuls I ke siklus II meningkat $30,7 \%$. 


\section{Peningkatan Ketrampilan Metakognisi dalam Proses Pembelajaran}

1) Peningkatan ketrampilan perencanaan (planning Skills) berdasarkan komponen penilaian mahasiswa mulai berdiskusi untuk membuat perencanaan dengan berbagi tugas antar anggota kelompok untuk memahami masalah yang kompleks menjadi yang lebih sederhana. Ketrampilan perencanaan tidak hanya membantu untuk menciptakan solusi tapi juga membantu untuk lebih memahami permasalahan itu sendiri. Proses perencanaan menggiring kita untuk berpikir kembali atau merangkai masalah kembali. Ketrampilan perencanaan mahasiswa dalam siklus I dan siklus II menjadi peningkatan sebesar $25 \%$,

2) Peningkatan ketrampilan monitoring (monitoring skills) berdasarkan komponen bertujuan untuk memeriksa terhadap proses atau untuk mengevaluasi kondisi (Arikunto, 2006). Mulyasa (2006) menyebutkan monitoring bertujuan untuk: 1) mengkaji kembali apakah kegiata-kegiatan yang dilaksanakan telah sesuai dengan rencana, 2) mengidentifikasi masalah yang timbul agar langsung dapat diatasi, 3) melakukan penilaian apakah pola yang digunakan sudah tepat agar pencapaiarn proses pembelajaran , 4) mengetahui kaitan antara kegiatan dengan tujuan pembelajaran untuk memperolehukurankemajuan peserta didik. Ketrampilan monitoring mahasiswa dalam siklus I dan siklus II menjadi peningkatan sebesar 30\%, komponen berisi tentang proses pengumpulan dan menganalisis informasi secara sistematis dan melakukan tindakan koreksi sehingga kegiatan selanjutnya lebih baik.

3) Peningkatanketrampilanevaluasi(evaluation skills). Evaluasi adalah proses penilaian pencapaian tujuan dan pengungkapan masalah kinerja untuk memberikan umpan balik bagi peningkatan kualitas kinerja itu sendiri. Tujuan dari ketrampilan evaluasi adalah untuk mendaptakan informasi menarik dari pengalaman dari kegiatan yang baru selesai dilaksanakan, maupun yang sudah berfungsi sebagai umpan balik bagi pengambilan keputusan dalam rangka perencanaan, pelaksanaan, pemantauan dan pengendalian pembelajaran selanjutnya (Sukmadinata, 2005) komponen yang diterapkan disini adalah mahasiswa mencari informasi sebanyak mungkin untuk memecahkan masalah yang disajikan dan menarik pengambilan keputusan dari hasil diskusi bersama kelompok. Ketrampilan evaluasi mahasiswa dalam siklus I dan siklus II menjadi peningkatan sebesar 25\%.

4) Peningkatan ketrampilan prediksi (prediction skills). Prediksi berdasarkan hasil observasi yang cermat dan inferensi tentang hubungan antara beberapa kejadian yang terjadi selama proses pembelajaran berlangsung. Komponen ini mengajak mahasiswa untuk mencermatipermasalahan dan pemecahannya dengan mengkaitkan pengetahuan yang sudah diperolehnya dahulu untuk digabungkan dengan informasi yang diperoleh dari literatur dan hasil diskusi untuk kemudian digunakan dalam mengimajinasikan kemungkinan atas gabungan informasi yang sudah dimilikinya. Ketrampilan prediksi mahasiswa dalam siklus I dan siklus II menjadi peningkatan sebesar $23 \%$. Hasil penelitian terjadi peningkatan rerata hasil belajar siklus 1 ke siklus II yang signifikan, yaitu dari rerata skor 44,5 menjadi 69,3, serta peningkatan persentase ketuntasannya sebesar $40,3 \%$.

\section{PEMBAHASAN}

Hal yang paling menonjol dari penelitian ini adalah rendahnya ketrampilan metakognisi mahasiswa dalam menyajikan perencanaan, menyajikan data dan hasil pemikiran dalam memecahkan masalah terutama pada penecahan masalah yang memerlukan pemikiran yang cukup tinggi. Penerapan Tutor Sebaya dipadukan dengan The Power of Two dapat meningkatkan ketrampilan metakognisi mahasiswa hasil belajar dan dalam proses pembelajaran. Hal ini dapat dilihat dari naiknya persentase ketrampilan metakognisi mahasiswa berdasarkan indikator -indikator yang diamati. Proses pembelajaran lebih aktif dimana siswa lebih banyak melakukan aktivitas belajar, berupa hubungan interaktif antar teman dan materi kuliah sehingga terdorong untuk menyimpulkan pemahaman dari pada hanya sekedar menerima materi (Arsianah: 2006). Menurut Bonwell (1995), pembelajaran aktif memiliki karateristikkarateristik : 1) penekanan proses pembelajaran bukan pada penyampaian informasi oleh peng- 
116 | Wilyati Agustina, Peningkatan Ketrampilan Metakognisi Mahasiswa ...

ajar melainkan pada pengembanganketrampilan berpikir kognitif yaitu pemikiran lebih analitis dan kritis terhadap pemecahan masalah yang disajikan dalam proses pembelajaran. 2) siswa tidak hanya mendengarkan materi secara pasif disini siswa lebih mudah dan leluasa dalam menyampaikan masalah yangdihadapi sehingga siswa yang bersangkutan terpacu semangatnya untuk mempelajari materi ajar dengan. Teman sebayanya 3) penekanan pada eksplorasi nilai dan sikap-sikap ilmiah yang berkenaan dengan materi pelajaran, membuat siswa yang kurang aktif menjadi aktif karena tidak malu lagi untuk bertanya dan mengeluarkan pendapat secara bebas. 4) siswa lebih banyak dituntut untuk berpikir kritis, menganalisa dan melalukan monitoring evaluasi apa saja yang kurang dalam mencari bahan-bahan materi untuk memecahkan masalah. Mendata kembali dari data yang umum hingga khusus lebih spesifik, 5) umpan balik yang lebih cepat akan terjadi pada proses pembelajaran.

\section{KESIMPULAN DAN SARAN}

Berdasarkan data, analisis data, dan pembahasan, maka dapat disimpulkan bahwa penerapan Tutor Sebaya dipadukan dengan The Power of Two dalam Matakuliah Kimia Dasar dapat meningkatkan ketrampilan Metakognisi Mahasiswa IKIP Budi Utomo Malang.

\section{DAFTAR RUJUKAN}

Arikunto, S. 2006." Prosedur Penelitian Suatu Pendekatan Praktik". Edisi Revisi VI. Jakarta. Rineka Cipta.

Arsiana, R. 2006.Materi Sarana Berpikir Ilmiah, (Online), http://permatayien.blogspot.com. diakses 10 desember 2014).

Beti Riawati http://10310258.blogspot.com/2012/01/ model-pembelajaran-tutor-sebaya.html

Bonwell,C.C (1995).Active Learning: Creating Excitement in the classroom. Center for Teaching and Learning. St. Louis College of Pharmacy.

Corebima, A.D. 2009. Metakognition Skills Measurement Integrated in Achiement Test. Makalah disajikan dalam Third International Conference on Science and Mathematic Educatioan (CosMED). Malaysia, 10-12 November.

Febrianto, Aditya. 2013. Pengaruh Metode Pembelajaran Tutor Sebaya Terhadap Hasil Belajar Dribble Bola Basket (Studi Pada Siswa Kelas VII SMP Negeri 1Prambon Sidoarjo). Skripsi. Tidak diterbitkan, UNESA. Surabaya.

Muhfahroyin. 2009. Memberdayakan Kemampuan Berpikir Kritis, (Online), (http:zanikhan. multiply.com/journal/item/5570/ Memberdaykan-KemampuanBerpikir-Kritis.Html). diakses tanggal 26 Desember 2014.

Miranda, A.2014. Penerapan Strategi The Power of Two dengan Hasil Pembelajaran IPS Di Kelas V.Jurnal Pendidikan dan Pembelajaran Vol 3.No7.

Nur, M. 2008. Teori-Teori Pembelajaran Kognitif Cetakan 3. Surabaya: PSMS Unesa.

Sanjaya, W.2006.Strategi Pembelajaran Berorientasi standar dan Proses Pendidikan. Bandung:Prenda Media Grup.

Slavin, R. E. 1997. Educational Psychology Theory and Practice: Cognitive Theories of Learning Basic Conceps. Allyn and Bacon.

Sudarsono, F.X.1996/1997.Pedoman PTK Bagian Kedua: Rencana, Desain dan Implementasi. Jakarta: Dirjen Dikti, Departemen Pendidikan Nasional.

Sukmadinata. 2005. Landasan Proses Pendidikan. Bandung. PT Rosda Karya. Tim Redaksi Nuansa Aulia.

Supriono, A.2006. Cooperatif Learning.(Teori \& Aplikasi PAIKEM). PT Rosda Karya 